\title{
DFT Study of $p$-tert-Butylcalix[6]aryl Ester Complexed with Alkylammonium Ions
}

\author{
Kwangho Kim and Jong-In Choe \\ Department of Chemistry, Chung-Ang Lniversity, Seoul 156-756, Korea. ${ }^{*}$ E-mail: choejacau ac.kr \\ Received December 5. 2008. Accepted Jamarv9. 2009
}

\begin{abstract}
We have performed DFT B3LYP/6-31G(d,p) calculations to investigate the complexation behaviors of the ethyl ester derivative of $p$-fert-butylcalix[6]arene (1) toward a variety of alkylammonium ions. We have studied the binding sites of these host-guest complexes focusing on the p-tert-butylcalis[6]arene pocket (endo) of 1 . The smaller alky lammonium cations have the better complexation efficiency than the bulkier alkylammonium ions with the p-tert-butylcalix[6]aryl ester. The hydrogen-bonding of $\mathrm{N}-\mathrm{H} \cdots \mathrm{O}$ is one of the important factors for the complexation behavior of the p-tent-butylcalix [6]aryl ester, in addition to the $\mathrm{NH}$-aromatic $\pi$, CH-aromatic $\pi$ and electrostatic interactions, and the steric hindrance of alkylammonium cation. The hydrogen-bonded distances and angles of $\mathrm{N}-\mathrm{H} \cdots \mathrm{O}$ are reported for the complexes of the p-tert-butylcalix[6] aryl ester with various alkylammonium ions.
\end{abstract}

Key Words: DFT, B3L YP/6-31G(d.p), Calix[6]aryl ester, Alkylammonium ions. Hỵdrogen bond

\section{Introduction}

The selective recognition of many important biogenic amines is one of the fundamental research interest in the field of the host-guest chemistry: ${ }^{1 \cdot 3}$ Calix[6]arene a class of cyclic hexamers of phenol formaldehyde condensation product. seems to be more attractive for the design of larger organic guest ions. because they have larger cavities and therefore are expected to provide a more favorable versatile platform for the formation of inclusion complexes with many interesting guest molecules. ${ }^{4}$ Even though some progress has been made on the design of suitably functionalized calixarene derivatives for the molecular recognition of amine and related compounds. a lot remains to be clarified. ${ }^{5.6}$ For example, Shinkai et al. have reported that the trimethylammonium head group of some quatemary ammonium salt is predominantly included in the calixarene cavity via cation- $\pi$ interaction between $\pi$-base cavity of calix[6]arenes. Ethyl ester derivatives of $p$-tertbuty lcalix[6]arene (1) are known to have high affinity toward alkali metal ions. alkylammonium, and related cations. ${ }^{8.9}$ Recently. 1.3-bridged calix[5]crown-6-ether (2) was investigated as a tool for the shape recognition of alkylammonium ions in focusing the endo-versus exo-cavity complexation. ${ }^{\text {ji.11 }}$

Various important computational approaches in a variety of interesting supramolecular șystem are published. "2 We have reported computer simulations on molecular recognition of alkylammonium ions by ethỵl ester derivative of p-tertbutylcalix[6]arene (1) by using molecular mechanics (MM) and semi-empirical AMI methods. ${ }^{13}$ In that study the endocomplex was reported as the most stable stnicture among different orientations of alkylammonium cations complexed inside the cone-shaped host. Complexes of aromatic ring with ammonium cations. which are very important in biological systems. were already studied using $a b$ initio calculations. ${ }^{14.15}$ Endo-calix complexations of alkylammonium cations by p-tert-calix[5] aryl ester have also been calculated by using the ab initio HF/6-31G method. ${ }^{16}$

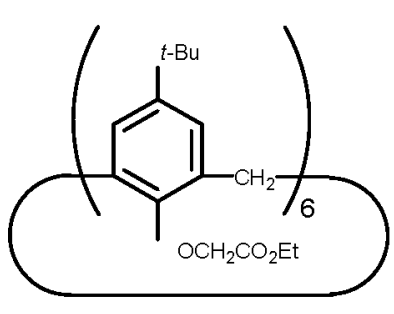

1

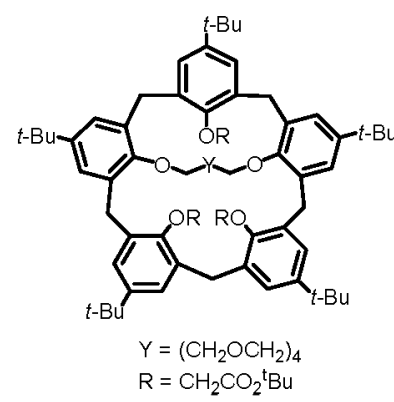

2
Scheme 1. Chemical structures of (a) p-tert-butylcalix[6]ary] ethy] ester 1 and (b) 1,3-bridged p-tert-butylcalix[5]crom-6-ether 2 .

${ }^{l} \mathrm{H}$ NMR complexation study of 1 with ethylanumonium picrate guest suggests the conformational reorganization to the cone conformation has provoked upon the complex formation. Also. an NMR study on complexation of ethylammonium ion by alkyl p-tert-butylcalix[6]aryl ester derivatives showed that the endo-type complexes are formed. ${ }^{18}$

In this paper. we have calculated the optimized energies and binding sites of calix[6]aryl ester (1) toward alkylammonium guests by using the DFT B3LYP/6-3IG(d.p) calculation method, ainuing to understand more deeply the complexational belavior of many related biologically interesting guests.

\section{Computational Methods}

The initial structures of host 1 and alkylammonium guest molecules were constructed by Hyperchem. ${ }^{19}$ The lowest energy structures of host 1 and complexes obtained from the Molecular Mechanics (MM) and Molecular Dynamics calculations were re-optinized by using the AMl seni-enpirical quantum mechanical method.

The density functional theory $(D F T)^{20.21}$ methods are effective for the theoretical studies of supramolecular com- 
plexes. ${ }^{21-2 r i}$ B 3LYP, a version of the DFT method, which uses a Becke's three-parameter functional (B3) and a mixture of HF with DFT exchange terms associated with the gradient corrected correlation functional of T ce, Yang, and Parr (I,YP) ${ }^{27}$

LF' B3LYL/6-3lG(d,p) full optimizations of the structures of host 1 and its alkylammonium complexes obtained from AM1 semi-empirical method were pertonmed to get the lowest energies and the stable struetures by using (jatssian $03^{28}$

\section{Results and Discussion}

Endo-Cone-type Complex. Many dilierent contomations (conc, a partial cone, threc- $\mid(1,2),(1,3),(1,4)]$-altemates, three-[(1,2,3), (1,2,4), (1,3,5)]-altemates) are possible for calix[6]arene. "? Without binding any alky lammonium guest. our calculations suggest that the 1,2,3-altemate confomational isomer of tree host 1 is more stable than the cone analogue. ${ }^{13.2 .9}$ However, an NMR study on the complexation of ethylam monium or $n$-propylammonium cation by alkyl p-tert-butylcalix|6|aryl ester derivatives indicated that the guest is held tightly deep in the cone-shape aromatic cavity of calixarene, thus foming endo-ty pe complex. ${ }^{18}$ It was reported that, upon the complexation, the methyl and methylene protons in alkylammonium guest undergo uplield shifts by 2.6 and 2.9 ppm, respectively. The interaction of calixarene derivatives with primary alkylammonium ion is also reported to be originated from the complexation through a tripodal arrang ement of $\mathrm{N}^{-}-\mathrm{II} \cdots \mathrm{O}=\mathrm{C}($ host $)$ hydrogen bonds and $\mathrm{R}-\mathrm{NHI}_{3}{ }^{-} \cdots$ $O=C(h o s t)$ charge dipole interaction. " the large upfield shilts observed are thought to anise from the so-called $\mathrm{CH}-\pi$ interaction and indicate that the ethyl group side of the guest is embedded in the cavily and subject on the ring cumrent of phenyl groups. The endo-type complexation may be caused predominantly by this interaction. ${ }^{18}$ Therefore, we have toused our elforts to endo-cone-shaped complexes.

$D F T$ B3LYP/6-31 G(d,p) Calculations. The $D F T$ liull optimizations were carried out for the ento-complexation mode ol 1 by combining the cone contormer of host 1 with various alkylanmonium cations. The results of $\mathrm{B} 3 \mathrm{LYP} / 6-31 \mathrm{G}(\mathrm{d}, \mathrm{p})$ complexation energies of the complexes of calix[6]aryl ester (1) and 1,3-bridged $p$-tert-butylcalix $|5|$ crown-6-ctlier $(2)^{11}$ with alkylammonitum ions are listed in Table 1

From Table 1, the more meaning ful data than the absolute energies are the complexation energies ( $\mathrm{E}_{\text {conplax }}-\mathrm{E}_{\text {Host }}-\mathrm{E}_{\text {(juest }}$ ). The smaller alkylammonium cations have the better complexation efficiency with $p$-te?t-butylcalix|6/aryl ester than bulky alkylammonium ions. We can sort the complex ation energies of nine alkylanmonium complexes in lable 1 into three groups: the $\mathrm{NH}_{1}^{-}$, methyl and ethyl anmonium complexes are $8-10 \mathrm{kcal} / \mathrm{mol}$ more stable than $n$-propyl, iso-propyl and $n$-butyl anmonium, and $20 \sim 30 \mathrm{kcal} / \mathrm{mol} \mathrm{mote}$ stable than the branched butyl ammonium analogues. One should note that in the gas phase it is natural that smaller calionic species such as $\mathrm{NH}_{4}{ }^{+}$should have higher binding energy than larger cationic species. IJowever, in the presence

Table 1. DFT calculated complexalion energies ${ }^{\prime \prime}$ ol the p-tert-butylcalis[6]ary] ester (1) and 1.3-bridged $p$-tert-butylcalix[5]crown-6-etler (2) with alky Jammonimm ions

\begin{tabular}{|c|c|c|c|c|c|c|c|c|c|}
\hline Guest $^{t}$ & $\mathrm{NH}_{4}^{+}$ & Mc & Et & ${ }_{n n}-\mathrm{Pr}$ & isco-Pr & $n-B u$ & $i s c u-\mathrm{Bu}$ & $\sec -\mathrm{Bu}$ & $\operatorname{tent-Bu}$ \\
\hline Conte-typé Host & \multicolumn{9}{|c|}{ Endo-Complexes with Cone-lype Host } \\
\hline 1 & -91.24 & -89.77 & -91.02 & -82.52 & -83.06 & -79.59 & -69.89 & -73.42 & -59.22 \\
\hline $2^{d}$ & -82.80 & -73.56 & -66.77 & -66.56 & -57.40 & -65.22 & -54.62 & -49.11 & -49.14 \\
\hline
\end{tabular}

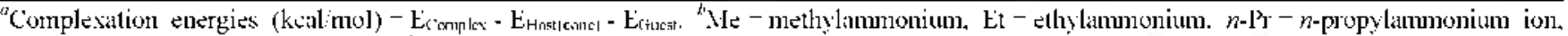

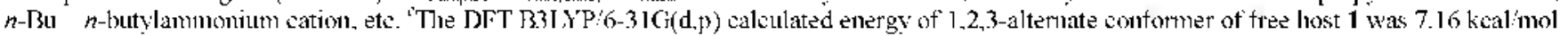
more stable that1 the cone-lype host 1 . However, we have shesen the cone-shaped host for the caleulation of complexation energy nelative to the ende-cone-1ype complex. Error limits in these calculations are about $0.01 \mathrm{ktal}$ mol. "Data are taken from the previously published relerente 11.

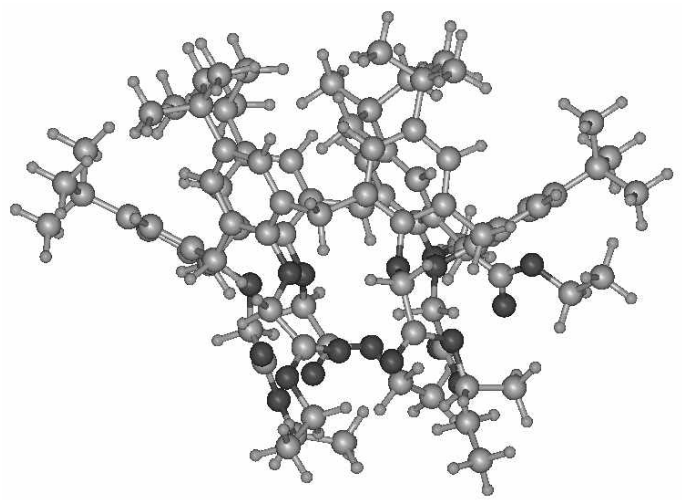

(a) Come-lype Ilosi 1 (PosNol)

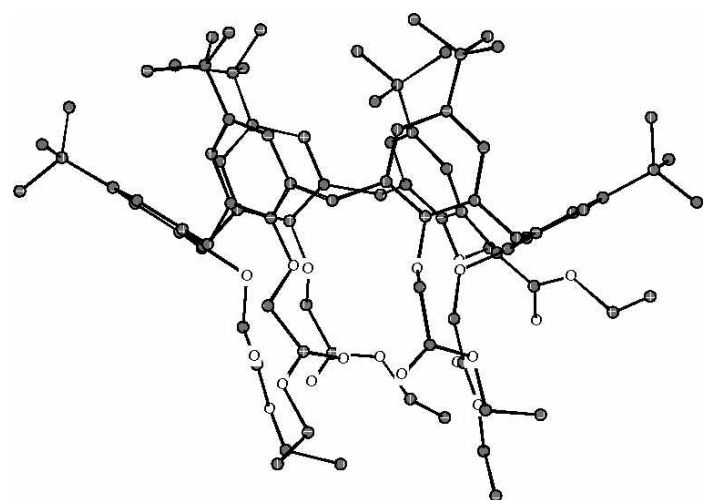

(b) Host 1 (Chem3]))

Figure 1. DFT calculated cone confomation of the tre host 1. Figure l(a) shows all atoms by using PosMol ${ }^{31}$ and Figure 1 (b) is drawn by using Chem $3 \mathrm{D}^{32}$ wilhout bydrogen atoms for clarity. 


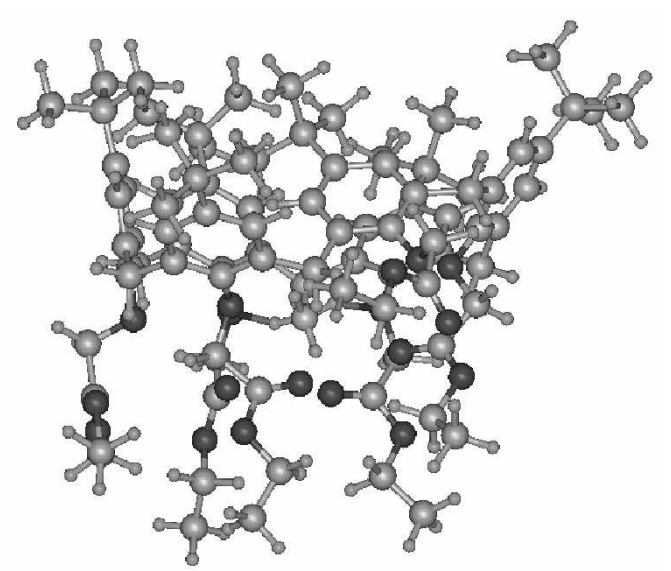

(a) $\mathbf{1} \mathrm{NH}_{4}{ }^{\prime}\left(\mathrm{l}^{2} \mathrm{O} \mathrm{\textrm {M } M O}\right)$

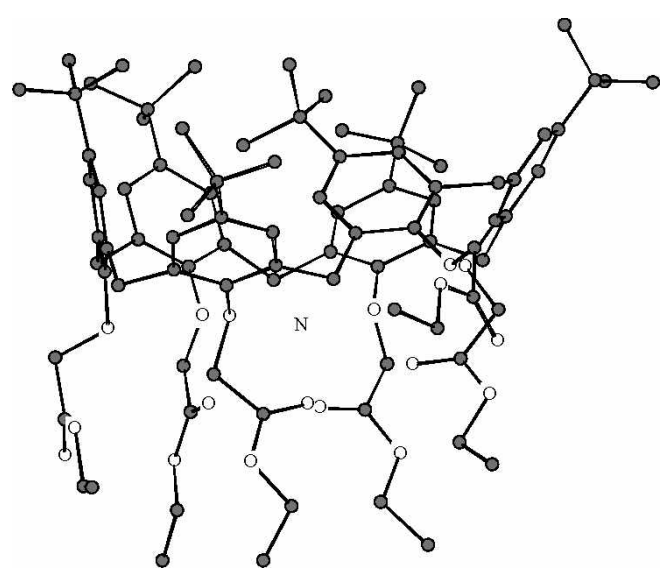

(b) $1 \cdot \mathrm{NII}_{4} \cdot($ Chem.31)

Figue 2. DTT calculated structures of the endo-cone-type ammonium complex (1-NI ${ }_{4}{ }^{\circ}$ ). Figure 2(a) shows all atoms including the hydrogen bondings. Figure 2 (b) is drawn without bydrogen atons for clarity:

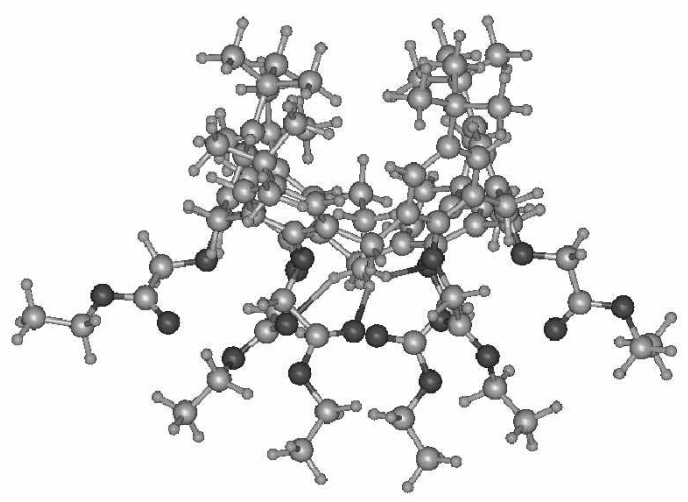

(a) 1-Fit (l'osMol)

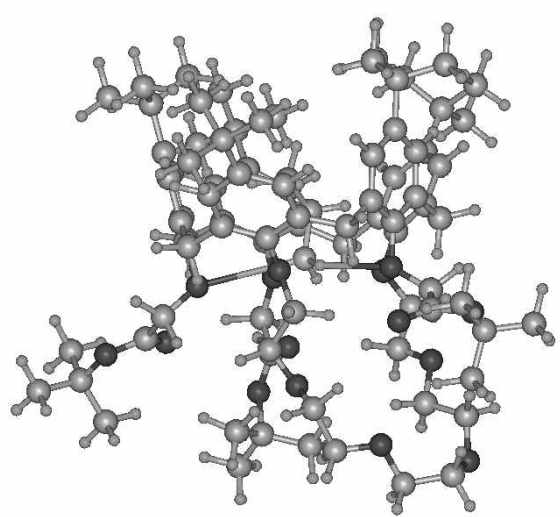

(c) 2.Fil (l'osMol)

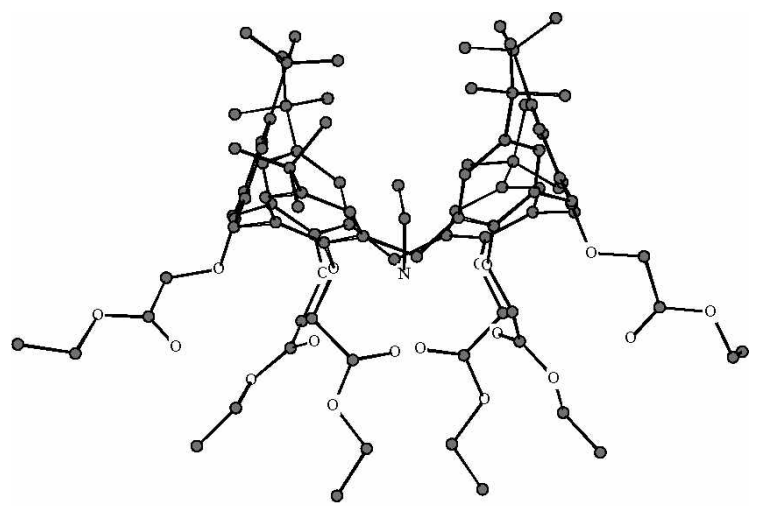

(b) 1.Et (Chem3D)

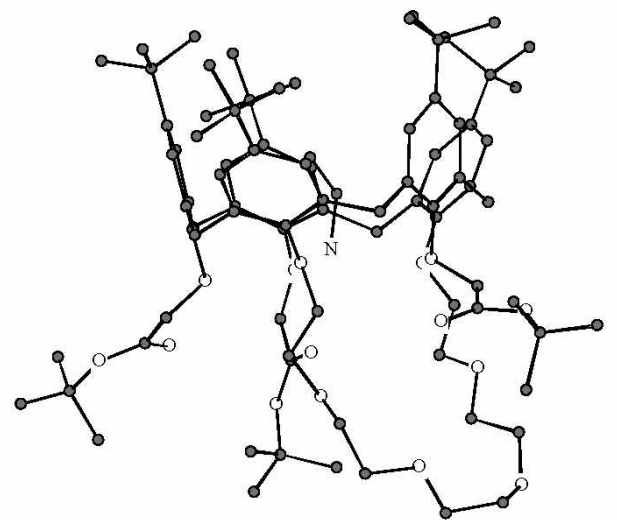

(d) 2.Et (Chem3D)

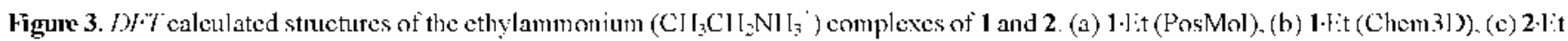
(PosMol), and (d) 2.1:t (Chem.3J)).

of solvents, a specific size of cations (rather than a smaller cation) would more selectively bind receptors. 60.30

Figures 1 to 6 show the $D F T$ optimized structures of 1 and the ento-cone-type complexes of 1 with some of the alkytammonium cations. Figure 2(a) shows all atoms including the bydrogen bondings of ammonium complex $\left(1 \cdot \mathrm{NT} \mathrm{I}^{+}\right)$by using PosMol." Figure 2(b) is drawn without hydrogen atoms for clarity by using (hem 31).2 Figures $3(a)$ and $3(b)$ shows the ethylammonium (CI $\mathrm{Cl}_{3} \mathrm{CI}_{2} \mathrm{NI}_{3}{ }_{3}^{\prime}$ ) complexes of 1 , and Figures 3(c) and $3(d)$ shows the ethylamnonium complexes of 2 . Addition to the NI I-aromatic $\pi$, CI I-aromatic $\pi$ and electrostatic interactions, and the steric hindrance of alkylammonium cation, the hydrogen-bonding of $\mathrm{N}-\mathrm{H} \cdots \mathrm{O}$ ) is one of the important factors for the complexation efficiency of the p-te\%-buty lealix[6]aryl ester with varying structures of the guest ions. From the calculated structures, the distarices from nitrogen atom in alky lammoniun guest ion to oxygen atoms in a cone-shaped host 1 are reported in Table 2. The 


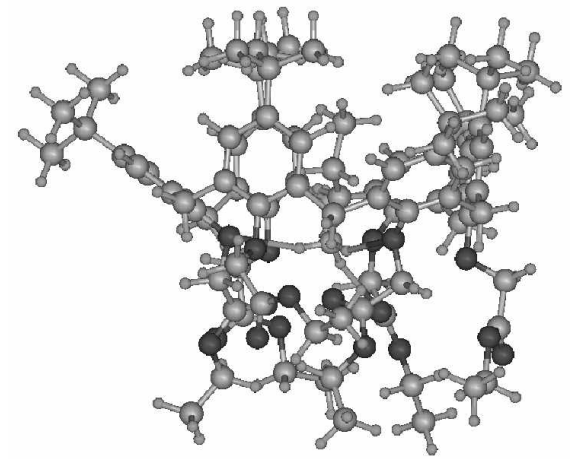

(a) $\left.1 / n-\mathrm{P}^{\mathrm{P}} \mathrm{r}(\mathrm{P} \mathrm{P}) \mathrm{MMol}\right)$

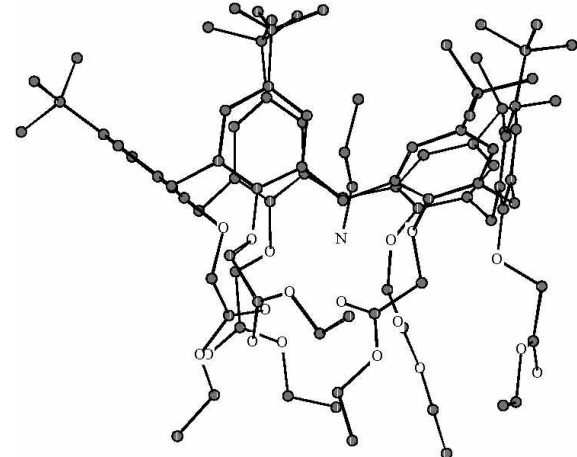

(b) $\mathbf{I} n-\mathrm{P}^{3} \mathrm{r}(\mathrm{C}$ (hem.3 $\mathrm{I})$

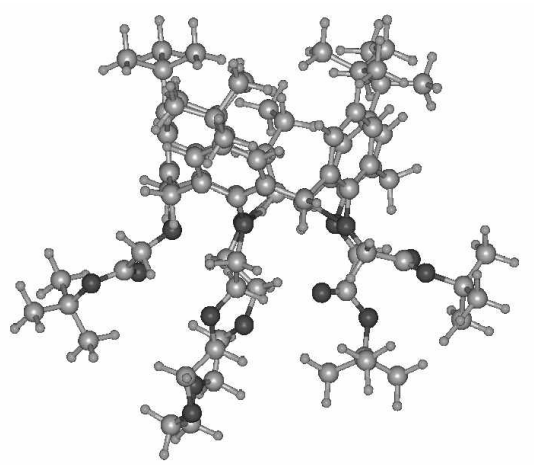

(c) $2 \cdot n-\mathrm{l}^{2} \mathrm{r}\left(\mathrm{l}^{\prime}(\mathrm{s}, \mathrm{Mol})\right.$

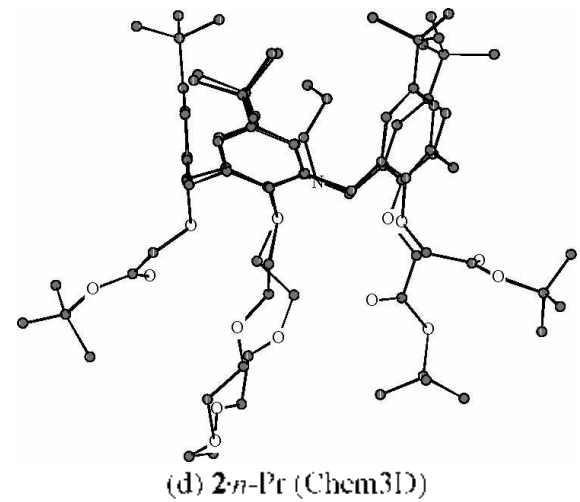

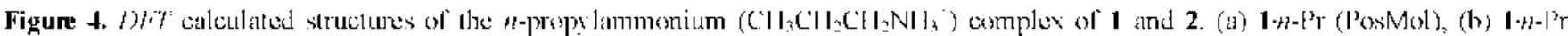

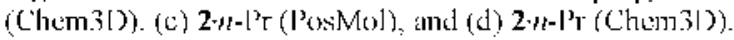

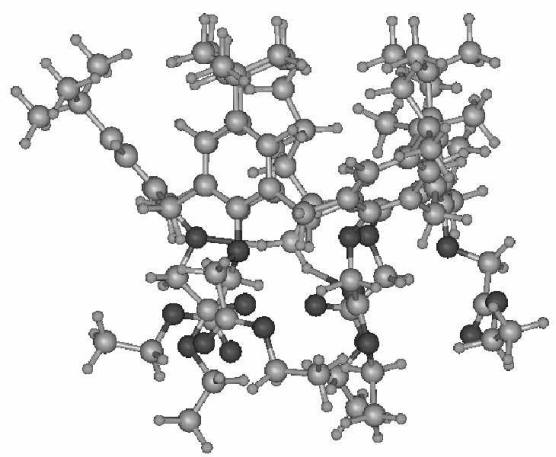

(a) $1 \cdot n-13 u\left(P^{2} 0 \mathrm{MMol}\right)$

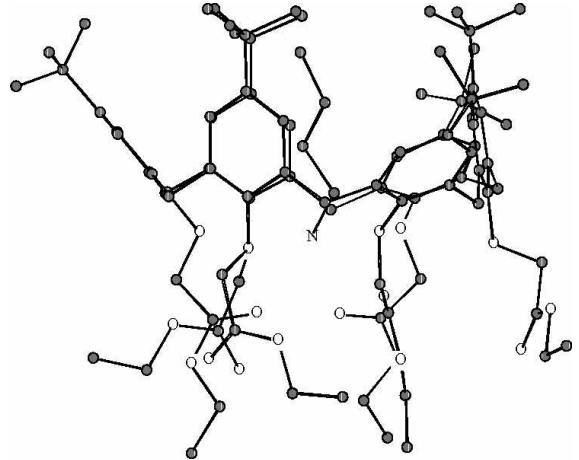

(b) $1 \cdot n-\mathrm{Bu}(\mathrm{Chem} 3 \mathrm{D})$

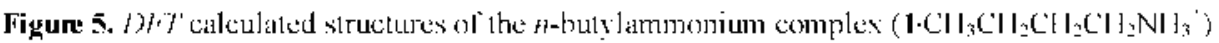

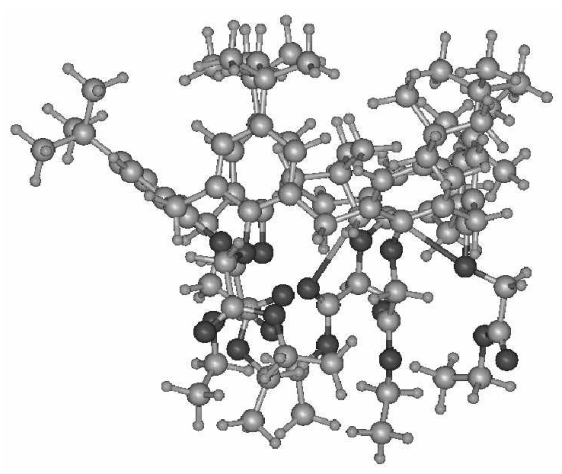

(al) 1.t-]3u (I'osMol)

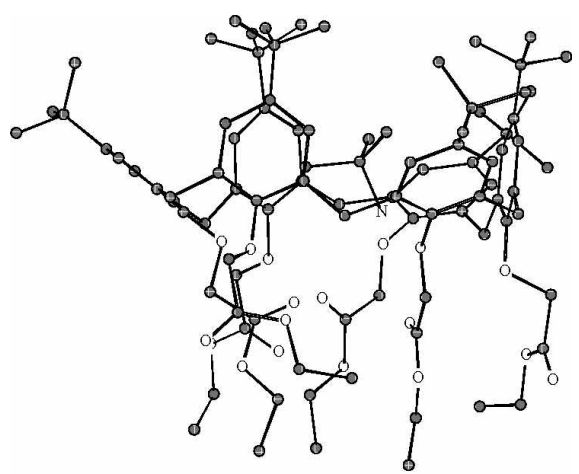

(b) $1 \cdot t$-Bu (Chem3D)

Figure 6. $D / 7$ ' calculated structures of the ferf-buty lammonium complex $\left(1 \cdot\left(\mathrm{CH}_{3}\right)_{3} \mathrm{CNH}_{3}\right)$ 
Table 2. DFT B3LYP/6-31G(d,p) Calculated Distances $(\AA)$ and Angles (N-H $\cdots$ O) of Hydrogen Bonds between 1 and alkylammonium ions

\begin{tabular}{|c|c|c|c|c|c|}
\hline Complex & H-bond & 1 & 2 & 3 & Average \\
\hline \multirow[t]{4}{*}{$1 \cdot \mathrm{NH}_{+}^{-}$} & $\mathrm{N} \cdots \mathrm{O}$ & 3.078 & 3.173 & 3.276 & 3.176 \\
\hline & $\mathrm{H} \cdots \mathrm{O}$ & 2.109 & 2.397 & 2.380 & 2.295 \\
\hline & N-H & 1.032 & 1.023 & 1.024 & 1.026 \\
\hline & Angle & 155.3 & 131.9 & 1456 & 144.3 \\
\hline \multirow[t]{4}{*}{$1 \cdot \mathrm{Me}$} & $\mathrm{N} \cdots \mathrm{O}$ & 2.930 & 3.206 & & 3.068 \\
\hline & $\mathrm{H} \cdots \mathrm{O}$ & 1.919 & 2.279 & & 2.099 \\
\hline & $\mathrm{N}-\mathrm{H}$ & 1.032 & 1.026 & & 1.029 \\
\hline & Angle & 165.9 & 149.5 & & 157.7 \\
\hline \multirow[t]{4}{*}{$1 \cdot \mathrm{Et}$} & $\mathrm{N} \cdots \mathrm{O}$ & 2.964 & 3.011 & 3.393 & 3.123 \\
\hline & $\mathrm{H} \cdots \mathrm{O}$ & 2.057 & 2.052 & 2.442 & 2.184 \\
\hline & N-H & 1.030 & 1.031 & 1.023 & 1.028 \\
\hline & Angle & 145.6 & 153.5 & 154.3 & 151.1 \\
\hline \multirow[t]{4}{*}{$1 n-\mathrm{Pr}$} & $\mathrm{N} \cdots \mathrm{O}$ & 2.992 & 3.287 & & 3.140 \\
\hline & $\mathrm{H} \cdots \mathrm{O}$ & 2.064 & 2.308 & & 2.186 \\
\hline & N-H & 1.032 & 1.024 & & 1.028 \\
\hline & Angle & 148.4 & 159.5 & & 153.9 \\
\hline \multirow[t]{4}{*}{1 iso- $\mathrm{Pr}$} & $\mathrm{N} \cdots \mathrm{O}$ & 3.018 & 3.029 & 3.217 & 3.088 \\
\hline & $\mathrm{H} \cdots \mathrm{O}$ & 2.109 & 2.110 & 2.354 & 2.191 \\
\hline & N-H & 1.026 & 1.026 & 1.025 & 1.026 \\
\hline & Angle & 146.6 & 147.8 & 141.2 & 145.2 \\
\hline \multirow[t]{4}{*}{$1 n-\mathrm{Bu}$} & $\mathrm{N} \cdots \mathrm{O}$ & 2.957 & 3.135 & 3.149 & 3.080 \\
\hline & $\mathrm{H} \cdots \mathrm{O}$ & 2.076 & 2.134 & 2.384 & 2.198 \\
\hline & N-H & 1.027 & 1.026 & 1.026 & 1.026 \\
\hline & Angle & 142.4 & 164.6 & 130.5 & 145.8 \\
\hline \multirow[t]{4}{*}{ 1-iso-Bu } & $\mathrm{N} \cdots \mathrm{O}$ & 3.049 & $3.06 \hat{3}$ & & 3.056 \\
\hline & $\mathrm{H} \cdots \mathrm{O}$ & 2.162 & 2.588 & & 2.375 \\
\hline & N-H & 1.022 & 1.026 & & 1.024 \\
\hline & Angle & 144.2 & 107.9 & & 126.1 \\
\hline \multirow[t]{4}{*}{ 1.sec-Bu } & $\mathrm{N} \cdots \mathrm{O}$ & 3.161 & 3.332 & & 3.247 \\
\hline & $\mathrm{H} \cdots \mathrm{O}$ & 2.257 & 2.360 & & 2.309 \\
\hline & N-H & 1.024 & 1.027 & & 1.026 \\
\hline & Angle & 146.4 & 157.5 & & 152.0 \\
\hline \multirow[t]{4}{*}{$1 t-\mathrm{Bu}$} & $\mathrm{N} \cdots \mathrm{O}$ & 3.226 & & & 3.226 \\
\hline & $\mathrm{H} \cdots \mathrm{O}$ & 2.302 & & & 2.302 \\
\hline & N-H & 1.026 & & & 1.026 \\
\hline & Angle & 149.1 & & & 149.1 \\
\hline
\end{tabular}

Table 3. DFT Calculated ( $N \cdots$ O) Distances $(\AA)^{\prime \prime}$ of Hydrogen Bonds between 2 and Alkylammonium Ions

\begin{tabular}{lcccc}
\hline Complex & 1 & 2 & 3 & Average \\
\hline $2 \cdot \mathrm{NH}_{4}{ }^{-}$ & 2.746 & 2.777 & 2.790 & 2.771 \\
$2 \cdot \mathrm{Me}$ & 2.852 & 2.905 & 2.934 & 2.897 \\
$2 \cdot \mathrm{Et}$ & 2.784 & 2.840 & 2.972 & 2.865 \\
$2 \cdot \cdots-\mathrm{Pr}$ & 2.863 & 2.877 & 2.881 & 2.874 \\
$2 \cdot 7 \mathrm{so}-\mathrm{Pr}$ & 2.880 & 2.929 & 3.008 & 2.939 \\
$2 \cdot 7-\mathrm{Bu}$ & 2.849 & 2.853 & 3.028 & 2.910 \\
$2 \cdot i s o-\mathrm{Bu}$ & 2.857 & 2.943 & 2.951 & 2.917 \\
$2 \cdot 5 e c-\mathrm{Bu}$ & 2.967 & 3.034 & & 3.001 \\
$2 \cdot+\mathrm{Bu}$ & 2.969 & 2.990 & & 2.980 \\
\hline
\end{tabular}

"Data are taken from the previously published reference 11 . unusual stability of the branched iso-propylammonium complex is originating from the three $\mathrm{H}$-bonds of iso-propylanmonium versus two $\mathrm{H}$-bonds of the $n$-propylanmonium analogue.

When one look at the hydrogen-bonding data of $\mathrm{N}^{\cdots} \mathrm{O}$ in Table 2, the average distances (3.07-3.18 A) of the smaller and linear alkylammonium-complexes are shorter than the values $(3.23-3.25 \mathrm{~A})$ of the bulky sec- and tert-butylammonium-complexes. One of the $\mathrm{N} \cdots \mathrm{O}$ distances in tertbutylammonium-complex $(3.749 \AA)$ is out of the range of normal $\mathrm{H}$-bond distance. ${ }^{33}$ Therefore, this $\mathrm{H}$-bond data is deleted from the Table 1 . And the average distances $(2.10-2.30 \AA)$ of the $\mathrm{H} \cdots$ O distances of the linear alkylanunonium-conplexes are shorter than the values $(2.30-2.38 \AA)$ of the branched butylammonium-complexes. For the host 1. the binding site is the cavity consisted of six benzene rings which provide two types of $\mathrm{NH}$-aromatic $\pi$ and $\mathrm{CH}$-aromatic $\pi$ interactions. ${ }^{15}$ When one compares the DFT calculated complexation energies of host $\mathbf{1}$ with previously reported host $\mathbf{2}$ in Table 1. p-tert-butylcalix[6]aryl ester (1) shows much better (9-25 $\mathrm{kcal} / \mathrm{mol}$ ) binding efficiencies toward alkylammonium ions than 1.3-bridged p-tert-buty'lcalix[5]crown-6-ether (2) having five benzene rings, although the average $\mathrm{N} \cdots \mathrm{O}$ distances $(2.77-3.00 \AA \text { in Table } 3)^{11}$ of the complexes of 2 were shorter than the values (3.07-3.25 A in Table 2 ) of 1.

\section{Conclusion}

We have performed DFT B3LYP/6-3/G(d.p) calculations for the endo-complexation of the p-tert-butylcalix[6]aryl ethyl ester with a series of alkylammonium ions. Complexation with the smaller and linear alkylammonium ion usually shows the better complexation efficiency than the bulkier alkylammonium ion. and also displays shorter hydrogenbond distances. Addition to the $\mathrm{NH}$-aronatic $\pi . \mathrm{CH}$-aronatic $\pi$ and electrostatic interactions. and the steric hindrance of alky lammonium cation. the hydrogen-bonding of $\mathrm{N}-\mathrm{H} \cdots \mathrm{O}$ is one of the important factors for the complexation efficiency of the p-tert-butylcalix[6]aryl ester with varying structures of the guest ions. DFT calculated complexation energies of p-tert-butylcalix[6]aryl ester (1) show better $(9-25 \mathrm{kcal} / \mathrm{mol})$ binding efficiencies toward alkylammonium ions than p-tertbutỵlcalix[5]crown-6-ether (2).

Aclnowledgments. This research was supported by the Chung-Ang University research grants in 2008. The large portions of the computations were carried out with use of the computer facilities at the Research Center for Computational Science of the Okazaki National Research Institutes in Japan.

\section{Refeiences}

1. (a) Inctusion Phenontena and Wolecular Re cogntition; Atwood, T. L. Ed: Plenum Press: New York, 1989. (b) Calitarenes: A Iersatile Class of Aacrocuclic Componthds; Vicens, T.; Böhmer, V., Eds.: Kluwer Academic Publishers: Dordrecht, The Netherlands, 1991.

2. Balzani, V; De Cola, L. Supramolecular Chemistry; Kluwer Academic Publishers: Dordrecht, The Netherlands, 1992. 
3. (a) Fages, F.: Desvergne, J-P.; Kannke, K.: Bouas-Laurent, H.: Lehn, I.-M:: Meyer, M.: Albrecht-Gary, A.-M. J. Am. Chem. Soc. 1993, 115, 3658. (b) Behr, J.-P; Lehn, J.-M; Vierling, P. Helv Chim Acta 1982, 65, 1853 . (c) Bradshaw, J S.; Baxter, S. L.: Lamb, T. D.: Izatt, R. M.; Christensen, I. I. J. Ant. Chent. Soc. $1981,103,1821$

4. (a) Rogers, I. S.: Gutsche, C. D. J. Org. Chem. 1992, $57,3152$. (b) Kanamathareddy; S.; Gutsche, C. D. J. Org. Chem. 1992, 57, 3160. (c) Casnati, A.: Minari, P.: Pochini, A.: Ungaro, R. J. Chem. Soc., Chem. Commun 1991, 1413 . (d) Neri, P.: Pappalardo, S. J. Org. Chem. 1993, 58, 1048. (e) Calixarenes $50^{\text {th }}$ Anmersam: Commemorative Lolume; Vicens, I, Asfari, Z; Harrow field, T. M., Eds.; Kluwer Academic Publishers: Dordrecht, The Netherlands, 1991. (f) Gutsche, C. D. Calixarenes Rerisited, Roval Society of Chemistry: Cambridge, 1998. (g) Calixanenes in.tction. Mandolini, L.: Ungaro, R., Eds.; World Scientific Publishers Co.: Singapore, 2007

5. Gutsche, C. D.: See, K. A. J. Org. Chem. 1992, 57, 4527.

6. Bauer, L. I.: Gutsche, C. D. J. Am. Chem. Soc. 1985, I07, 6063.

7. Shinkai, S. Tetrahedron $1993,10,8933$

8. Shinkai, S.; Koreishi, H.; Ueda, K.: Arimura, T.; Manabe, O. $J$. Am. Chem. Soc. 1987, 109,6371

9. (a) Chang, S.-K.; Hwang, H.-S.: Son, H.: Youk, T.: Kang, Y. S. J. Chem. Soc., Chem Commun 1991,217. (b) Chang, S.-K.; Jang, M.: Han, S. Y.; Lee, J. H.: Kang, M. H.: No, K. T. Chent. Left. 1992, 1937. (c) Han1, S. Y.; Kang, M.-H.: Jung, Y. E.: Chang, S.-K. J. Chent. Soc. Perkin Trans. 2 1994, 835 (d) Lee, J. H.; Kim, T. H.; Chang, S.-K.; Choe, I.-I. Supramolectlar Chemistry $1995,+315$

10. Salvo, G. D.: Gattuso, G.; Notti, A.; Parisi, M.; Pappalardo, S. $J$. Org. Chem. 2002, 67,684.

11. Oh, D.-S.; Choe, J.-I. Bull. Korean Chem. Soc. 2007, 28, 596.

12. Computational Approaches in Supramolecthlar Chemistry; Wipff, G., Ed.; Kluwar Acadenic Publishers: Dordrecht, The Netherlands, 1994

13. Choe, J-I.: Kinn, K.: Chang, S.-K. Bull. Korean Chem. Soc. 2000, 21, 200

14. (a) Lee, J. Y.; Lee, S. T.; Choi, H. S.; Cho, S. I. Kim, K. S: Ha, T. K. Chem. Phys. Lett 1995, 232, 67. (b) Kim, K. S.: Lee, I. Y: Lee, S. T; Ha, T. K.; Kim, D. H. J. Am. Chem. Soc 1994, 16, 7399.

15. (a) Choi, H. S.: Cho, S. J.: Kim, K. S. Proc Natl Acad Sci. 1998, 95, 12094. (b) Kinn, K. S.; Cui, C.; Cho, S. J. J. Phys. Chem 1998, 102, 46I. (c) Cho, S. J.; Hwang, H.; Park, J.; Oh, K. S.: Kin, K. S. J. Am Chem. Soc. 1996, $118,485$.

16. Choe, T.-I.; Lee, S. H.; Oh, D.-S.; Chang, S.-K.; Nanbu, S. Bull. Korean Chem. Soc 2004, 25, 190.

17. Alu1, S.: Chang, S.-K.: Kim, T.; Lee, T. W. Chem. Lett. 1995, 4, 297
18. Ahn, S.: Mun, C. S.; Chung, K. S.: Oh, W. S.: Chang, S.-K.; Lee, I. W. Bull. Korean Chem. Soc. $1998,19,68$

19. HiperChem Release 7.5, Hypercube, Inc.: Waterloo, Ontario, Cánada, 2002.

20. Hohenberg, P.; Kolu1, W. Phvs. Rev B 1964, 136, 785.

21. Koln, W.: Sham, L. J. Phus. Rev . $1965,140,1133$.

22. Sreeruttun, R. K.: Ramasami, P.; Yan, G.; Wannere, C. S.; Schlever, P. v. R.; Schaefer, H. F. Int. J. Hass Spectrom. 2005, 241,295

23. Zandler, M. E.; D'Souza, F. C. R. Chimie. 2006, 9, 960

24. Karr, P. A.: Zandler, M. E.; Beck, M., Jaeger, I. D.: McCarty, A. L.; Smith, P. M.; D Solza, F. J. Mol. Strwct. Theochem.) 2006 , 765,91

25. Su, C. C.: Lu, L. H.; Lill, L. K. J. Phys Chem . $12003,107,4563$.

26. Hsieh, T. J.; Su, C. C.; Chen, C. Y.; Liou, C. H.; Lu, L. H. J. Hol. Struct. 2005, 741, 193

27. Lee, C.: Yang, W.: Pan, R. G. Phss. Rev. B 1988, 37, 785.

28. Frisch, M. I.; Trucks, G. W; Schlegel, H. B.; Scuseria, G. E: Robb, M. A.; Cheeseman, I. R.; Montgomery, II., I. A.; Vreven, T.; Kudin, K. N.; Burant, J. C.; Millam, J. M; Iyengar, S. S.; Tomasi, J.: Barone, V.: Mennucci, B.: Cossi, M.; Scalmani, G.; Rega, N.: Petersson, G. A.; Nakatsuji, H.; Hada, M.: Ehara, M.; Toyota, K; Fukuda, R.; Hasegawa, I.; Ishida, M; Nakajima, T; Honda. Y.: Kitao. O.: Nákáli. H.: Klene. M.: Li. X.: Knox. J. E.: Hratchian, H. P.; Cross, J. B.; Bakken, V; Adamo, C.; Taramillo, I.; Gomperts, R.; Stratmann, R. E; Yazyev, O.; Austin, A. T.; Cammi, R.; Pomelli, C : Ochterski, J. W.: Ayala, P. Y: Morokuma, K; Voth, G. A.; Salvador, P.; Dannenberg, T. J.; Zakrzewski, V. G.: Dapprich, S.: Daniels, A. D.: Strain. M. C.: Farkas, O.: Malick, D. K; Rabuck, A. D.; Raghavachari, K.; Foresman, J. B.; Ortiz, I. V.; Cui, Q.; Baboul, A. G.; Clifford, S.; Cioslowski, I.: Stefanov, B. B.: Lill, G.: Liashenko, A.; Piskorz, P.: Komaromi, I.; Martin, R. L.; Fox, D. J.; Keith, T.; Al-Laham, M. A.; Peng, C. Y.; Nanayakkara, A.; Challacombe, M.; Gill, P. M. W.; Johnson, B.: Chen, W.; Wong, M. W.; Gonzalez, C.; Pople, J. A. Gaussion 03, Revision D.01: Gaussian. Inc: Wallingford, CT, 2004.

29. See the relative energy $(7.16 \mathrm{kcal} / \mathrm{mol})$ between the cone and $1,2,3$-altemate conformers in the footnote " $\mathrm{c}$ " of Table 1 .

30. Choe, H. S.: Kim, D.: Tarakeshwar, P.: Suh, S. B.: Kim, K. S. J. Org. Chem. 2002, 67, 1848 .

31. Lee, S. J.; Chung, H. Y.; Kim, K. S. Bull. Korean Chem. Sac. 2004, 25, 1061

32. Chem3D, Iersion 7.0; Cambridge Soft, Cambridge, MA, U.S.A., 2001

33. Teffrey, G. A. An hitroluction to Hydrogen Bonding, Oxford University Press: Cambridge, 1997. 